\title{
Chlorophyllin as a possible measure against vectors of human parasites and fish parasites
}

\author{
Peter R. Richter ${ }^{1 *}$, Sebastian M. Strauch ${ }^{1}$, Azizullah Azizullah ${ }^{2}$ and Donat-P. Häder ${ }^{3}$ \\ 1 Department of Biology, Cell Biology, Friedrich-Alexander-University Erlangen-Nuremberg, Erlangen, Germany \\ ${ }^{2}$ Department of Botany, Faculty of Biological Sciences, Kohat University of Science and Technology, Kohat, Pakistan \\ ${ }^{3}$ Friedrich-Alexander-Universität Erlangen-Nürnberg, Möhrendorf, Germany
}

\section{Edited by:}

Rajeshwar P. Sinha, Banaras Hindu

University, India

Reviewed by:

Olimpio Montero, Spanish Council

for Scientific Research (CSIC), Spain Shailendra Pratap Singh, Michigan

State University, USA

\section{*Correspondence:}

Peter R. Richter, Department

Biologie, Cell Biology, Gravitational

Biology, Friedrich-Alexander-

Universität Erlangen-Nürnberg,

Staudtstr. 5, 91058 Erlangen,

Germany

e-mail: peter.richter@fau.de
Water soluble chlorophyll (chlorophyllin) exerts pronounced photodynamic activity. Chlorophyllin is a potential remedy against mosquito larvae and aquatic stages in the life cycle of parasites as well as against ectoparasites in fish. In the recent years it was found that mosquito larvae and other pest organisms can be killed by means of photodynamic substances such as different porphyrin derivates (e.g., hematoporphyrin, meso-tri(N-methylpyridyl), meso-mono(N-tetra-decylpyridyl) porphyrine, hematoporphyrin IX, or hermatoporphyrin formula (HPF). It was found that incubation of mosquito larvae in chlorophyllin solution and subsequent irradiation results in photodynamic destruction of the larvae. Incorporation of about $8 \mathrm{ng}$ chlorophyllin per larvae was sufficient to induce its death. In fish mass cultivation ichthyophthiriosis is a severe parasitic protozoan disease caused by the ciliate Ichthyophthirius multifiliis. It was found that incubation of infected fishes in chlorophyllin and subsequent illumination reduced the number of trophonts significantly (more than 50\%). The fishes were not impaired. Chlorophyllin and other photodynamic substances may become a possible countermeasure against $I$. multifiliis and other ectoparasites in aquaculture. The effectiveness of chlorophyllin depends on light attenuation in the water body.

Keywords: chlorophyllin, photodynamic substance, ectoparasite, Ichthyophthirius multifiliis, aquaculture, mosquito larvae, E170

\section{BRIEF INTRODUCTION TO PHOTODYNAMIC REACTIONS}

In general photodynamic substances $\left({ }^{3} \mathrm{P}\right)$ are not toxic in darkness, but are activated by light and transformed to a reactive triplet state $\mathrm{T} 1$. Upon reaction with oxygen $\left({ }^{3} \mathrm{O}_{2}\right)$ reactive singlet oxygen is produced $\left({ }^{1} \mathrm{O}_{2}\right)$, which has highly cytotoxic effects (Kessel and Smith, 1989; DeRosa and Crutchley, 2002).

$$
{ }^{3} \mathrm{P}+{ }^{3} \mathrm{O}_{2} \rightarrow \mathrm{P}+{ }^{1} \mathrm{O}_{2}
$$

A variety of chemicals undergo a reaction with light, among others porphyrins (the core structure of chlorophyll) and are employed in photodynamic therapy. The physical basics and applications of photosensitizers in oncology are reviewed by Hasan et al. (2003). Also chlorophyll and its derivates were found to show efficient photodynamic properties (Park et al., 1989; Scherz et al., 1994).

\section{HUMAN PARASITES AND THEIR VECTORS}

Poverty results in tremendous numbers of avoidable cases of death or many life years under reduced health conditions, respectively, because people often do not have access to basic needs such as clean drinking water or health care. Disability-adjustedlife-year (DALY) is a value where life lost due to premature mortality as well as years under conditions of not ideal health (YLD: years lived with disability) are taken into account (Vos et al., 2012). A Global Burden Disease Study where 235 causes of death in different age groups were investigated clearly demonstrated that above all children in developing countries die from avoidable diseases and infections such as diarrhoeal diseases, measles or malaria (Lozano et al., 2012). Tropical diseases contribute to low economic development of poor countries (RBM, 2007). Many severe parasitic diseases, bacteria and viruses are transmitted by dipters. Malaria is the tropical disease responsible for the highest number of casualties. Malaria is a disease caused by a protozoan (genus Plasmodium) transmitted by mosquitoes. The most important and deadly Plasmodium is P. falciparum, which is responsible for $80 \%$ of infections and about $90 \%$ of deaths. Due to enormous global achievements in order to combat malaria e.g., by the Bill and Melinda Gates Foundation, the number of new infection is decreasing but is still on an unacceptably high level. In the course of a systematic analysis of malaria mortality between 1980 and 2010, Murray et al. (2012) estimated about $1,133,000(848,000-1,591,000)$ deaths caused by malaria in 2010 (Lozano et al., 2012; Murray et al., 2012). According to the World Malaria report the number of estimated deaths in 2012 was about 627,000 $(437,000-789,000)$ (WHO, 2013). In addition a variety of so called "neglected tropical diseases" are responsible for a multiplicity of infections and deaths especially in developing countries (Hotez et al., 2008). Important "neglected tropical diseases" are among others schistosomiasis (caused by helminthes of the genus Schistosoma), onchocerciasis (a helminth infection by Onchocerca volvulus) or 
lymphiatic filiariasis (caused by helminthes such as Wucheria bancrofti). Infectious stages of Schistosoma, the cercaria, are produced by infected waters snails of the genus Biomphalaria or Bulinus and released into the water. The larva penetrate through the skin into the human body (Engels et al., 2002). Onchocerca volvulus and Wucheria bancrofti are transmitted by dipters. An overview about these diseases is given by Feasey et al. (2010). Hotez et al. (2007) estimate that life-years lost due to premature death or disability (Disability-adjusted-life-year) caused by 13 neglected tropical diseases is about 56.6 million years - more than in malaria where the number of Disability-adjusted-lifeyears was estimated to be about 46.5 million years (Hotez et al., 2007). Dengue fever is caused by a virus transmitted by the mosquito Aedes aegyptii. Worldwide about 390 million people are infected every year, about 20,000 die. About $50 \%$ of the world population lives in areas with risk of infection (Bhatt et al., 2013).

\section{POTENTIAL OF CHLOROPHYLLIN AND OTHER PHOTODYNAMIC SUBSTANCES IN CONTROL OF MOSOUITO LARVAE}

The most promising method to control diseases transmitted by animal vectors (e.g., flies or molluscs) is the control of these vectors. Application of pesticides, wetland draining, spraying of oil on water surfaces in order to kill mosquito larvae in combination with mosquito nets, medicine and support of natural predators are methods to defeat these diseases (Killeen et al., 2002). Photosensitizers were also successfully tested against mosquito larvae or as general pesticides (reviewed by Amor and Jori, 2000). Dondji et al. (2005) determined the effect of different photosensitizers on Aedes and Culex larvae. A concentration of $0.4 \mathrm{mg} / \mathrm{L}$ Rose Bengal was found to kill effectively $100 \%$ of Culex quinquefasciatus larvae. Hematoporphyrin was less effective against $C$. quinquefasciatus (necessary concentration for $\mathrm{LD}_{100} 8 \mathrm{mg} / \mathrm{L}$ ). Both substances were shown to kill Aedes aegypti, where Rose Bengal was again more effective. Awad et al. (2008) tested the efficiency of certain hematoporphyrins (hematoporphyrin IX and hermatoporphyrin formula (HPF) from a commercial source) against Culex pipiens. It was found that both chemicals induced high mortality in the insect larvae at low concentrations $(1 \mu \mathrm{M})$. In a recent study El-Tayeb et al. (2013) determined uptake kinetics and efficiency of HPF against Aedes caspicus larvae. By means of confocal microscopy it was found that after $12 \mathrm{~h}$ of incubation of larvae in HPF-containing water the body concentration of HPF reached a maximum. Erzinger et al. (2011) found that about $3 \mathrm{~h}$ of chlorophyllin incubation in Chaoborus crystallinus are necessary in order to achieve an optimal accumulation of the photosensitizer in the intestine of the larvae. Lucatoni et al. (2011) intensively characterized another porphyrin (C 14 porphyrin, meso-tri(N-methylpyridyl), meso-mono(Ntetradecylpyridyl)porphyrine) and tested the effect against Aedes aegypti. It was found that after incubation in " $\mathrm{C} 14$ porphyrin" $(5 \mu \mathrm{M})$ and subsequent light treatment larvae were effectively killed. Some studies demonstrate that porphyrins are also applicable as insecticides against land living insects (Amor et al., 2000, 2008; Wu et al., 2007). Photodynamic properties of chlorophyllin in dipter larvae was intensively investigated (Wohllebe et al., 2009). After accumulation of chlorophyllin in the intestine light treatment resulted in high mortality. Untreated larvae were almost not affected. The $\mathrm{LD}_{50}$ dose of externally applied chlorophyllin (addition to the water body) was about $6.88 \mathrm{mg} / \mathrm{l}$ in Culex larvae and about $24 \mathrm{mg} / \mathrm{l}$ in Chaoborus larvae (Wohllebe et al., 2009). Uptake of about $8 \mathrm{ng}$ of chlorophyllin was found to induce photodynamic damage in one larva (Wohllebe et al., 2011). Experiments with Chaoborus cristallinus indicate that chlorophyllin and light induce necrosis and apoptosis in the intestines of the insect larvae (Wohllebe et al., 2011). The gut of irradiated larvae showed many apoptotic or necrotic cells as detected with fluorescence microscopy after staining with suitable dyes (acridine orange for detection of necrosis, Hoechst 33342 for detection of necrosis and propidium iodide-detection of apoptosis). FACS analysis of cells from irradiated and not-irradiated cells clearly showed an increase of apoptotic and necrotic cells in irradiated larvae.

\section{PARASITES IN AQUACULTURE}

In fishery many infectious diseases are known to inflict severe damage to fish (Paperna, 1991; Lom and Dyková, 1992). Fishes become often host of ectoparasites, because their soft skin is easy to penetrate and the parasites find themselves in an aquatic environment (no dehydration). Due to the high numbers of fish in ponds and recirculation systems or due to the combination of different environmental factors, incidence of parasitoses is favored (Hines and Spira, 1973). A few thousands of ectoparasites of fishes from different classes are known. Important parasites with strong impact in aquaculture are e.g., Ichthyophthirius multifiliis, Trichodina sp., Dactylogyrus spp., Gyrodactylus sp. and Costia sp. High losses in life-stock are accounted for by the most widespread and most important parasitosis, called ichthyophthiriasis or "white spot disease" caused by the ciliate Ichthyophthirius multifiliis (Cross and Matthews, 1992). Due to its low host specificity this parasite is found on diverse fishes in various environmental conditions. Ichthyophthirius multifiliis shows a life cycle with three distinct stages (Matthews, 2005; Schuhmacher, 2011). The trophic stage is the trophont, which feeds on the skin or gills of fish. It reaches a size of up to $1 \mathrm{~mm}$ and forms a typical white spot. When trophonts become fertile they leave the fish and transform themselves to tomonts. By rapid cell divisions the encysted form of the parasite produces up to several thousand theronts (tomites), which are the highly infective life-stages of Ichthyophthirius multifiliis (Figure 1). Theronts most likely recognize their host by chemical stimuli (Haas et al., 1998). After infestation of the skin, eyes or gills of the fish the theronts develop to trophonts again. Due to the enormous multiplication capacity of this parasite the whole fish stock in an aquaculture can be infected within a short time. Under uncontrolled infection of the fish stock the injuries inflicted by the trophonts leads to high mortality rates. Fish become immune after moderate contact with Ichthiophthirius (Dickerson and Dawe, 1995) but due to the high population density in modern aquaculture the parasite reaches deadly concentrations within a short time when the water temperature is in an optimal range. At $26^{\circ} \mathrm{C}$ Ichthiophtirius needs only $6 \mathrm{~h}$ to perform a complete life cycle (Wahli-Moser, 1985). 


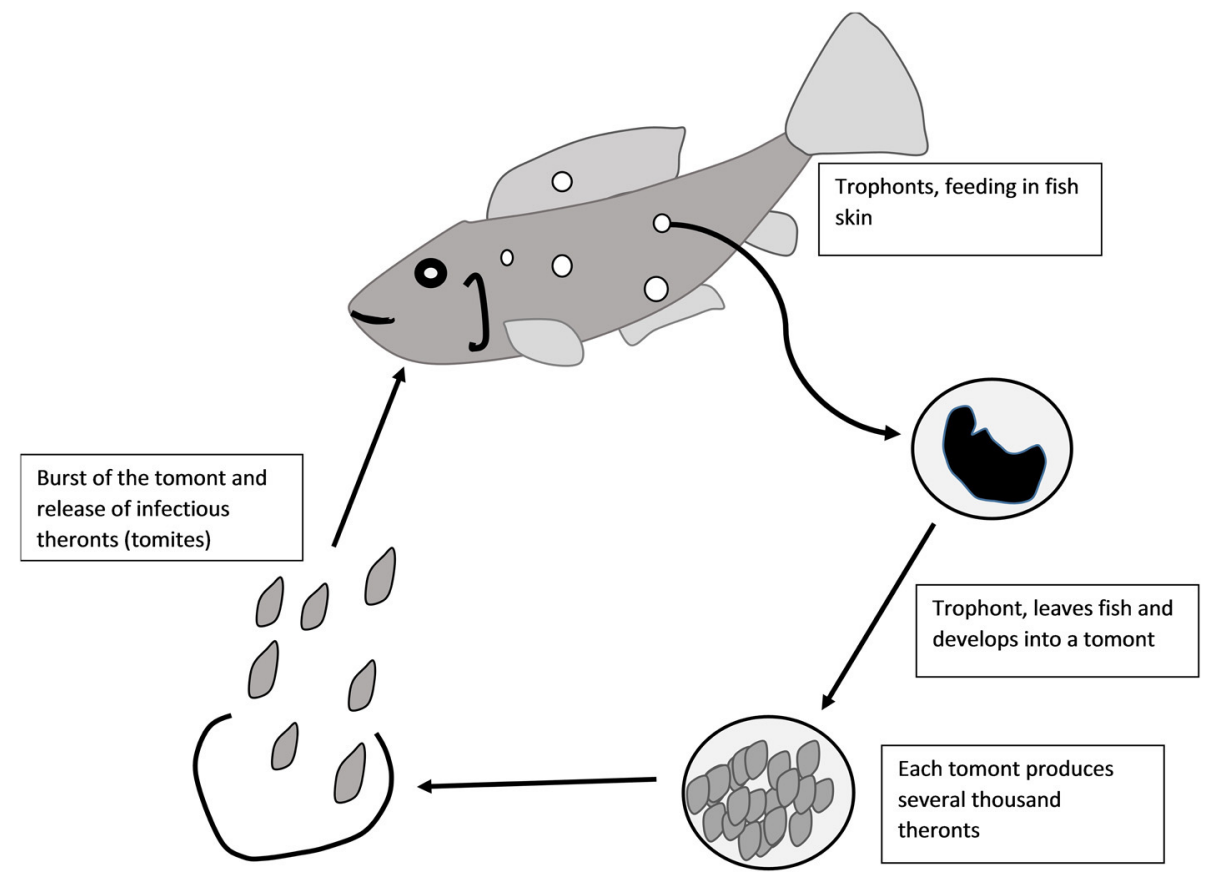

FIGURE 1 | Simplified scheme of the life cycle of the fish parasite Ichthyophthirius multifiliis.

One of the most important remedies against ichthyophthiriosis was malachite green, which effectively kills free living theronts and tomonts, but not the trophonts (Sudova et al., 2007). As malachite green was found to be most likely carcinogenic its application in fish used for food production is meanwhile prohibited in the European Community [regulation (EU) Nr. 37/2010]. Alternatives to malachite green were intensively investigated (Selosse and Rowland, 1990; Wahli et al., 1993; Tiemann and Goodwin, 2001). Legal alternatives in ichthyophthirasis treatment are sodium chloride, peroxide and formaldehyde (Sudova et al., 2007). These chemicals are not very efficient against ichthyophthiriasis so that no potent remedy against the parasites is available. Experiments with oral application of quinine yielded promising results (Schmahl et al., 1996; Schuhmacher, 2011), but an application for the use in aquaculture is not yet in sight. An increase of the water temperature above $30^{\circ} \mathrm{C}$ for several days, which would lead to destruction of Ichthyophthirius is hardly applicable due to technical reasons or because of temperature requirements of the fishes. This lack of an effective countermeasure against ichthiophthiriosis results in a state of emergency in therapy of infected fishes. There are no absolute numbers available, but the costs in aquaculture caused by infectious diseases are considerably.

\section{POTENTIAL OF PHOTODYNAMIC SUBSTANCES AGAINST PARASITES IN AOUACULTURE}

Recently the effects of photodynamic substances, in particular chlorophyllin, on fish parasites (above all Ichthiophthirius multifiliis) were investigated. Same as other photoactive compounds (Reddi et al., 2002; Maisch et al., 2005a,b) photodynamic application of chlorophyllin was found to have antimicrobial effects (Kreitner et al., 2001; López-Carballo et al., 2008). Fabris et al. (2012) reported that the " $\mathrm{C} 14$ porphyrin" (see above) is highly efficient against different small crustaceans and ciliated protozoa. Application of chlorophyllin kills effectively free living stages of Ichthyophthirius multifiliis as well as isolated trophonts at low concentrations (Wohllebe et al., 2012). The $\mathrm{LD}_{50}$ for (isolated) trophonts was determined as $0.67 \mathrm{mg} / \mathrm{L}$. In tomites no threshold was determined, because of the high sensitivity of the tomites against photoactivated chlorophyllin $(<<2 \mathrm{mg} / \mathrm{L})$.

\section{EFFECTS OF CHLOROPHYLLIN ON TROPHONTS OF ICHTHYOPHTHIRIUS MULTIFILIIS LOCATED IN THE FISH SKIN}

Having observed the severe effect of chlorophyllin on different isolated living stages of Ichthyophthirius, Wohllebe (2010) investigated the effect on trophonts located in the skin of carps: I. multifiliis-infested common carps were incubated for $3 \mathrm{~h}$ in chlorophyllin solution (2 and $4 \mathrm{mg} / \mathrm{L}$, which corresponds to about 3.35 or $6.7 \mu \mathrm{M}$, respectively). Controls were treated in the same way without chlorophyllin. After incubation one set of fishes was irradiated with simulated solar radiation for $3 \mathrm{~h}$, the other incubated fishes were kept under dim light conditions (no irradiation). It was shown that light exposure alone transiently reduced the number of trophonts in infested carps. Without chlorophyllin, irradiation alone reduced the number of trophonts transiently. After $24 \mathrm{~h}$ the number of counted parasites was reduced to $80.2 \%$ of the initial number but after some time the infection recovered. When the carps were incubated in chlorophyllin ( 2 or $4 \mathrm{mg}$, respectively) before irradiation, the infection was strongly reduced (to about $50 \%$ of the initial number of trophonts) and the number of trophonts did not increase again. Chlorophyllin without subsequent irradiation did not reduce the 
number of trophonts. Subsequent mesocosm experiments where 2 year-old carps were treated with $2 \mathrm{mg} / \mathrm{L}$ chlorophyllin confirmed these observations. Irradiation without previous chlorophyllin treatment reduced Ichthyophthirius multifilis trophonts only transiently, while incubation in chlorophyllin before irradiation resulted in a significant and steady decrease of the number of trophonts (about 50\% of the initial number). Interestingly chlorophyllin treatment without subsequent irradiation increased the number of trophonts compared to untreated controls.

These experiments revealed that trophonts in the fish skin are sensitive against chlorophyllin. In addition, no reinfection occurred in the course of some days, which indicates that the trophonts and other life stages of I. multifiliis were probably impaired in a way that the remaining parasites lost the capacity of multiplication. Veterinaries state that the observed decrease in infestation very likely enables infected fishes to recover (oral communication). Photodynamic treatment of fish-parasitic protozoans, above all I. multifiliis, is covered by an US patent (US $6,506,791 \mathrm{~B} 2$ ), in which Phloxin B is employed as photodynamic substance (Blair, 2003).

The strong effects of chlorophyllin raise the question whether photodynamic substances also impair treated fishes. Wohllebe (2010) clearly demonstrated that vitality of developed fishes and fish eggs is not impaired by chlorophyllin. But high chlorophyllin concentrations were found to induce mortality in fish breed (about $50 \%$ of fish larvae died at chlorophyllin concentrations of $10 \mathrm{mg} / \mathrm{l})$. Histological analysis revealed that the mortality is probably due to slime induction in the gills leading to suffocation of the larvae. After the larval stage no negative effects of chlorophyllin on the fish were detected. Investigated were common carps (Cyprinus carpio), rainbow trouts (Oncorhynchus mykiss), and grayling (Thymallus thymallus). This shows that chlorophyllin can be applied in fish farming when fish have finished the larval stage.

\section{POSSIBLE APPLICATION OF CHLOROPHYLLIN IN THE FIELD AND AQUACULTURE}

Chlorophyllin is a certified food additive (E 170). The degradation of chlorophylls is well known and does not lead to accumulation of toxic intermediates (Heaton and Marangoni, 1996). In addition, chlorophyll was described to reduce toxic effects of aflatoxin in trouts (Breinholt et al., 1999), which is probably due to a chlorophyllin-dependent reduced absorption of the toxin in the intestine or aflatoxin complexion. Predicted problems in the application of photodynamic substances are the high amount of material which is needed for treatment of a large water body. Another question regards the light attenuation in the water column. Presently commercially available chlorophyllin is quite expensive. A reason for this is most likely that it is produced as colorant for the food industry which requires high standards in the technical processes. As long as no cheap chlorophyllin is available its application would be restricted to small ponds with high number of fish or intensive aquaculture. However, chlorophyllin can be extracted easily from cheap plant materials such as weeds or grass.
Regarding attenuation it was tested earlier that about 36 $\mathrm{W} / \mathrm{m}^{2}$ of visible daylight are sufficient to induce photodynamic destruction of Chaoborus crystallinus larvae (Erzinger et al., 2011). This is about $10 \%$ of the daylight reaching the water surface. The daylight intensity on bright days at mid-latitudes (Erlangen, Germany) can be seen in Häder et al. (1999). Wohllebe (2010) measured the light attenuation in four different carp ponds in order to determine the depth at which light is attenuated to $10 \%$ of its surface value. Depending on the turbidity in two ponds $10 \%$ of incident light reached about $2 \mathrm{~m}$, while in two other ponds where carp activity leads to strong turbidity light was already attenuated at a depth of about 20$30 \mathrm{~cm}$. This means, depending on the conditions of a pond or fish pool chlorophyllin can potentially be applied as a remedy against $I$. multifiliis and other ectoparasites. In a semi-field study Awad et al. (2008) demonstrated that it was possible to kill Culex larvae photodynamically in the presence of hematoporphyrin.

\section{EXTRACTION OF CHLOROPHYLL AND MODIFICATION TO WATER-SOLUBLE CHLOROPHYLLIN}

Chlorophyll can be extracted from green plant material with ethanol or methanol (Wohllebe et al., 2009). Heating to about $55^{\circ} \mathrm{C}$ for $2 \mathrm{~h}$ decreases extraction time and addition of small amounts of calcium carbonate prevents phaeophytin formation. Petroleum benzine is added to the filtered chlorophyll extract. Chlorophyll moves into the lipophilic petroleum benzine layer. This layer is removed and treated with small amounts of methanolic $\mathrm{NaOH}$ (about $1 \mathrm{~N}$ ). The ester bonding between the porphyrin ring of the chlorophyll (chlorophyllin) and the lipophilic phytol tail is cleaved and the water-soluble chlorophyllin moves into the methanolic $\mathrm{NaOH}$ solution.

\section{CONCLUSIONS AND PERSPECTIVES}

In conclusion, the data demonstrate that the treatment with chlorophyllin in combination with irradiation is effective against I. multifiliis and other ectoparasites as well as mosquito larvae.

- Mosquito larvae are photodynamically killed after uptake of chlorophyllin and subsequent irradiation.

- Chlorophyllin reduced considerably the number of trophonts in carps and probably strongly affected the surviving trophonts.

- In addition chlorophyllin reduces Aflatoxin-toxicity (Breinholt et al., 1999).

- Uptake of about $8 \mathrm{ng}$ of chlorophyllin leads to photodynamic destruction of mosquito larvae.

- Chlorophyllin is degraded very fast without formation of toxic byproducts.

- It is certified as food additive (E 170).

- Photodynamic activity is already induced at low light intensities enabling activity in deeper horizons of the water column.

We conclude that chlorophyllin may become a remedy against ectoparasites above all in intensive aquaculture plants with high density of fish. 


\section{REFERENCES}

Awad, H. H., El-Tayeb, T. A., and Abd El-Aziz, N. M. (2008). A semi-field study on the effect of novel hematoporphyrin formula on the control of Culex pipiens larvae. J. Agri. Soc. Sci. 4, 85-88.

Amor, B. T., Bortolotto, L., and Jori, G. (2000). Porphyrins and related compounds as photoactivatable insecticides. 3. Laboratory and field studies. Photochem. Photobiol. 71, 124-128. doi: 10.1562/0031-8655(2000)0710124SIPPAR2.0.CO2

Amor, B. T., and Jori, G. (2000). Insect Sunlight-activated insecticides: historical background and mechanisms of phototoxic activity. Biochem. Mol. Biol. 30, 915-925. doi: 10.1016/S0965-1748(00)00072-2

Amor, B. T., Tronchin, M., Bortolotto, L., Verdiglione, R., and Joril, G. (2008). Compounds as Photoactivatable insecticides1. phototoxic activity of hematoporphyrin toward ceratitis capitata and bactrocera oleae. Photochem. Photobiol. 67, 206-211. doi: 10.1111/j.1751-1097.1998.tb05188.x

Bhatt, S., Gething, P. W., Brady, O. J., Messina, J. P., Farlow, A. W., Moyes, C. L. et al. (2013). The global distribution and burden of dengue. Nature 496, 504-507. doi: $10.1038 /$ nature 12060

Blair, B. G. (2003). Patent N0.: (45) Date of Patent: US 6,506,791 B2 Jan. 14, 2003.

Breinholt, V., Arbogast, D., Loveland, P., Pereira, C., Dashwood, R., Hendricks, J., et al. (1999). Chlorophyllin chemoprevention in trout initiated by Aflatoxin B1 bath treatment: an evaluation of reduced bioavailability vs. target organ protective mechanisms. Toxicol. Appl. Pharmacol. 158, 141-151. doi: 10.1006/taap.1999.8696

Cross, M. L., and Matthews, R. A. (1992). Ichthyophthiriasis in carp, Cyprinus carpio L.: fate of parasites in immunized fish. J. Fish Dis. 15, 497-505. doi: 10.1111/j.1365-2761.1992.tb00681.x

DeRosa, M. C., and Crutchley, R. J. (2002). Photosensitized singlet oxygen and its applications. Coord. Chem. Rev. 233, 234, 351-371. doi: 10.1016/S00108545(02)00034-6

Dickerson, H. W., and Dawe, D. L. (1995). "Ichthyophthirius multifiliis and Cryptocaryon irritans (Phylum Ciliophora)," in Fish Diseases and Disorders, Vol. 1 Protozoan and Metazoan Infections, ed P. T. K. Woo (Wallingford, UK: cabdirect), 181-227.

Dondji, B., Duchon, S., Diabate, A., Herve, J. P., Corbel, V., Hougard, J.-J., et al. (2005). Assessment of laboratory and field assays of sunlight-induced killing of mosquito larvae by photosensitizers. J. Med. Entomol. 42, 652-656. doi: 10.1603/0022-2585(2005)042[0652:AOLAFA]2.0.CO;2

El-Tayeb, T. A., Abd El-Aziz, N. M., and Awad, H. H. (2013). A study on the dynamics of Aedes caspius larval uptake and release of novel haematoporphyrin. African Entomol. 21, 15-23. doi: 10.4001/003.021.0108

Engels, D., Chitsulo, L., Montresor, A., and Savioli, L. (2002). The global epidemiological situation of schistosomiasis and new approaches to control and research. Acta Trop. 82, 139-146. doi: 10.1016/S0001-706X(02)00045-1

Erzinger, G. S., Wohllebe, S., Vollrath, F., Souza, S. C., Richter, P., Lebert, M., et al. (2011). Optimizing conditions for the use of chlorophyll derivatives for photodynamic control of parasites in aquatic ecosystems. Parasitol. Res. 109, 781-786. doi: 10.1007/s00436-011-2322-7

Fabris, C., Soncin, M., Jori, G., Habluetzel, A., Lucantoni, L., Sawadogo, S., et al. (2012). Effects of a new photoactivatable cationic porphyrin on ciliated protozoa and branchiopod crustaceans, potential components of freshwater ecosystems polluted by pathogenic agents and their vectors. Photochem. Photobiol. Sci. 11, 294-301. doi: 10.1039/c1pp05154g

Feasey, N., Wansbrough-Jones, M., Mabey, D. C. W., and Solomon, A. W. (2010). Neglected tropical diseases. Br. Med. Bull. 93, 179-200. doi: $10.1093 / \mathrm{bmb} / \mathrm{ldp} 046$

Haas, W., Haberl, B., Hofmann, M., Kerschensteiner, S., and Ketzer, U. (1998). Theronts of Ichthyophtirius multifiliis find their fish hosts with complex behavior patterns and in response to different chemical signals. Tokai J. Exp. Clin. Med. 23, 329-331.

Häder, D. P., Lebert, M., Marangoni, R., and Colombetti, G. (1999). ELDONETEuropean light dosimeter network hardware and software. Photochem. Photobiol. B Biol. 52, 51-58.

Hasan, T., Ortel, B., Solban, N., and Pogue, B. (2003). Photodynamic therapy of cancer. Cancer Med. 7, 537-548.

Heaton, J. W., and Marangoni, A. G. (1996). Chlorophyll degradation in processed foods and senescent plant tissues. Trends Food Sci. Tech. 7, 8-15. doi: 10.1016/0924-2244(96)81352-5

Hines, R. S., and Spira, D. T. (1973). Ichthyophthiriasis in the mirror carp Cyprinus carpio L. I: Course of infection. J. Fish. Biol. 5, 385-392. doi: 10.1111/j.10958649.1973.tb04466.x
Hotez, P. J., Brindley, P. J., Bethony, J, M., King, C. H., Pearce, E. J., and Jacobson, J. (2008). Helminth infections: the great neglected tropical diseases. J. Clin. Invest. 118, 1311-1321. doi: 10.1172/JCI34261

Hotez, P. J., Molyneux, D. H., Fenwick, A., Kumaresan, J., Sachs, S. E., Sachs, J. D., et al. (2007). Control of neglected tropical diseases. Br. Med. Bull. 93, 179-200. doi: 10.1056/NEJMra064142

Kessel, D., and Smith, K. (1989). Photosensitization with derivatives of chlorophyll. Photochem. Photobiol. 49, 157-160. doi: 10.1111/j.1751-1097.1989.tb04090.x

Killeen, G. F., Fillinger, U., Kiche, I., Gouagna, L. C., and Knols, B. G. J. (2002). Eradication of Anopheles gambiae from Brazil: lessons for malaria control in Africa? Lancet Infect. Dis. 2, 618-627. doi: 10.1016/S1473-3099(02)00397-3

Kreitner, M., Wagner, K. H., Alth, G., Ebermann, R., Foissy, H., and Elmadfa, I. (2001). Haematoporphyrin- and sodium chlorophyllin-induced phototoxicity towards bacteria and yeasts - a new approach for safe foods. Food Control 12, 529-533. doi: 10.1016/S0956-7135(01)00057-3

Lom, J., and Dyková, I. (1992). Protozoan Parasites of Fishes. Amsterdam: Elsevier Science Publishers.

López-Carballo, G., Hernández-Muñoz, P., Gavara, R., and Ocio, M. J. (2008). Photoactivated chlorophyllin-based gelatin films and coatings to prevent microbial contamination of food products. Int. J. Food Microbiol. 126, 65-70. doi: 10.1016/j.ijfoodmicro.2008.05.002

Lozano, R., Naghavi, M., Foreman, K., Lim, S., Shibuya, K., Aboyans, V., et al. (2012). Global and regional mortality from 235 causes of death for 20 age groups in 1990 and 2010: a systematic analysis for the Global Burden of Disease Study 2010. Lancet 380, 2095-2128. doi: 10.1016/S0140-6736(12) 61728-0

Lucatoni, L., Magaraggia, M., Lupidi, G., Ouedraogo, R. K., Coppellotti, O., Esposito, F., et al. (2011). Novel, meso-substituted cationic porphyrin molecule for photo-mediated larval control of the Dengue vector Aedes aegypti. PLoS Negl. Trop. Dis. 5:e1434. doi: 10.1371/journal.pntd.0001434

Maisch, T., Bosl, C., Szeimies, R. N., Lehn, N., and Abels, C. (2005a). Antimicrobial agents and chemotherapy. Am. J. Soc. Microbiol. 49, 1542-1552. doi: 10.1128/AAC.49.4.1542-1552.2005

Maisch, T., Bosl, C., Szeimies, R.-M., Lehn, N., and Abels, C. (2005b). Photodynamic effects of novel XF porphyrin derivatives on prokaryotic and eukaryotic cells. Antimicrob. Agents Chemother. 49, 1542-1552. doi: 10.1128/AAC.49.4.1542-1552.2005

Matthews, R. A. (2005). "Ichthyophthirius multifiliis Fouquet and Ichthyophthiriosis in freshwater teleosts," in Advances in Parasitology, Vol. 59, eds J. R. Baker, R. Muller, and D. Rollinson (Oxford: Elsevier Science), 159-220.

Murray, C. J. L., Rosenfeld, L. C., Lim, S. S., Andrews, K. G., Foreman, K. J., Haring, D., et al. (2012). Global malaria mortality between 1980 and 2010: a systematic analysis. Lancet 379, 413-431. doi: 10.1016/S0140-6736(12)60034-8

Paperna, I. (1991). Diseases caused by parasites in the aquaculture of warm water fish. Annu. Rev. Fish Dis. 1, 155-194. doi: 10.1016/0959-8030(91)90028-I

Park, Y. J., Lee, W. Y., Han, M. J., and Kim, B. S. (1989). Chlorophyll derivatives: a new photosensitizer for photodynamic therapy of cancer in mice. Yonsei Med. J. 30, 212-218.

RBM. (2007). Economic Costs of Malaria. Available online at: http://www. rbm.who.int/cmc_upload/0/000/015/363/RBMInfosheet_10.htm

Reddi, E., Ceccon, M., Valduga, G., Jori, G., Bommer, J. C., Elisei, F., et al. (2002). Photophysical properties and antibacterial activity of meso-substituted cationic porphyrins. Photochem. Photobiol. 75, 462-470. doi: 10.1562/00318655(2002)0750462PPAAAO2.0.CO2

Scherz, A., Salomon, Y., and Fiedor L. (1994). Chlorophyll and bacteriochlorophyll derivatives, preparation and pharmaceutical compositions comprising them as photosensitizers for photodynamic therapy. Chem. Abstr. 120, 386.

Schmahl, G., Schmidt, H., and Ritter, G. (1996). The control of ichthyophthiriasis by a medicated food containing quinine: efficacy tests and ultrastructure investigations. Parasitol. Res. 82, 697-705. doi: 10.1007/s004360050188

Schuhmacher, I. V. (2011). Untersuchungen zur Wirksamkeit von Chinin gegen die Ichthyophthiriose bei Karpfen. Ph.D. thesis, Dissertation Tierärztlichen Fakultät der Ludwig-Maximilians-University Munich, Munich.

Selosse, P. M., and Rowland, S. J. (1990). Use of common salt to treat ichthyophthiriasis in Australian warmwater fishes. Prog. Fish Cult. 52, 124-127.

Sudova, E., Machova, J., Svobodova, Z., and Vesely, T. (2007). Negative effects of malachite green and possibilities of its replacement in the treatment of fish eggs and fish: a review. Veterinarni Medicina 52, 527. 
Tiemann, D. M., and Goodwin, A. E. (2001). Treatment for ich infestation in channel catfish evaluated under static and flow-through water conditions. Am. J. Aquacult. 63, 293-299. doi: 10.1577/1548-8454(2001) 063<0293:TFIIIC> 2.0.CO;2

Vos, T., Flaxman, A. D., Naghavi, M., Lozano, R., Michaud, C., Ezzati, M., et al. (2012). Years lived with disability (YLDs) for 1160 sequelae of 289 diseases and injuries 1990-2010: a systematic analysis for the Global Burden of Disease Study 2010. Lancet 380, 2164-2169. doi: 10.1016/S0140-6736(12) 61729-2

Wahli, T., Schmitt, M., and Meier, W. (1993). Evaluation of alternatives to malachite green oxalate as a therapeutant for ichthyophthiriosis in rainbow trout Oncorhynchus mykiss. J. Appl. Ichthyol. 9, 237-249. doi: 10.1111/j.14390426.1993.tb00400.x

Wahli-Moser, T. (1985). Ichthyophthiriasis bei der Forelle (Salmo sp.). Ph.D. thesis, Dissertation, University Basel, Basel.

WHO. (2013). World Malaria Report 2013. Geneva. ISBN: 9789241564694.

Wohllebe, S. (2010). Bekämpfung von Parasiten in aquatischen Ökosystemen mittels natürlicher Photosensitizer. Ph.D. thesis, University of Erlangen, Erlangen.

Wohllebe, S., Richter, P., and Häder, D.-P. (2012). Chlorophyllin for the control of Ichthyophthirius multifiliis (Fouquet). Parasitol. Res. 111, 729-733. doi: 10.1007/s00436-012-2893-y

Wohllebe, S., Richter, R., Richter, P. R., and Häder, D.-P. (2009). Photodynamic control of human pathogenic parasites in aquatic ecosystems using chlorophyllin and pheophorbid as photodynamic substances. Parasitol. Res. 104, 593-600. doi: 10.1007/s00436-008-1235-6
Wohllebe, S., Ulbrich, C., Grimm, D., Pietsch, J., Erzinger, G., Richter, R., et al. (2011). Photodynamic treatment of Chaoborus crystallinus larvae with chlorophyllin induces necrosis and apoptosis. Photochem. Photobiol. 87, 1113-1122. doi: 10.1111/j.1751-1097.2011.00958.x

Wu, R. H., Hu, S., Xu, H.-H., Wie, X. Y., and Hu, L. (2007). The synthesis and photolarvicidal activity of 2,5-diarylethynylthiophenes. Photochem. Photobiol. B Biol. 88, 180-184. doi: 10.1016/j.jphotobiol.2007.05.006

Conflict of Interest Statement: The authors declare that the research was conducted in the absence of any commercial or financial relationships that could be construed as a potential conflict of interest.

Received: 24 March 2014; paper pending published: 11 April 2014; accepted: 19 May 2014; published online: 05 June 2014.

Citation: Richter PR, Strauch SM, Azizullah A and Häder D-P (2014) Chlorophyllin as a possible measure against vectors of human parasites and fish parasites. Front. Environ. Sci. 2:18. doi: 10.3389/fenvs.2014.00018

This article was submitted to Environmental Toxicology, a section of the journal Frontiers in Environmental Science.

Copyright (c) 2014 Richter, Strauch, Azizullah and Häder. This is an open-access article distributed under the terms of the Creative Commons Attribution License (CC BY). The use, distribution or reproduction in other forums is permitted, provided the original author(s) or licensor are credited and that the original publication in this journal is cited, in accordance with accepted academic practice. No use, distribution or reproduction is permitted which does not comply with these terms. 